Invited review

\title{
Discovery and development of sulforaphane as a cancer chemopreventive phytochemical $^{1}$
}

\author{
Yuesheng ZHANG ${ }^{2}$, Li TANG \\ Department of Cancer Prevention and Control, Roswell Park Cancer Institute, Buffalo, New York 14263, USA
}

\author{
Key words \\ chemoprevention; phytochemical; isothio- \\ cyanate; sulforaphane; broccoli \\ ${ }^{1}$ Studies carried out in the authors' laboratory \\ were supported in part by US Public Service \\ Grants CA80962 and CA100623. \\ ${ }^{2}$ Correspondence to Dr Yuesheng ZHANG. \\ Phn 1-716-845-3097. \\ Fax 1-716-845-1144. \\ E-mail yuesheng.zhang@roswellpark.org
}

Received 2007-04-27

Accepted 2007-07-12

doi: $10.1111 / \mathrm{j} .1745-7254.2007 .00679 . \mathrm{x}$

\begin{abstract}
Sulforaphane (SF) is a phytochemical that displays both anticarcinogenic and anticancer activity. SF modulates many cancer-related events, including susceptibility to carcinogens, cell death, cell cycle, angiogenesis, invasion and metastasis. We review its discovery and development as a cancer chemopreventive agent with the intention of encouraging further research on this important compound and facilitating the identification and development of new phytochemicals for cancer prevention.
\end{abstract}

\section{Introduction}

Phytochemicals in broad terms are a synonym of plant chemicals (phyto is Greek for plant); however, in common usage the term is more limited in scope and usually refers to plant chemicals that are bioactive and are not part of the traditional nutrients, such as vitamins and minerals. Although these compounds are generally viewed as non-essential for normal body functioning, an increasing number of them have been shown to possess disease-fighting activities, including anticarcinogenic and anticancer activities ${ }^{[1-4]}$. In this review, we attempt to provide an overview of the discovery and development of sulforaphane (SF) as a cancer chemopreventive phytochemical. SF was isolated from broccoli in the early 1990s in our laboratory as an inducer of phase 2 enzymes and has since been extensively studied by numerous investigators and shows a highly promising cancer-fighting ability ${ }^{[5-10]}$.

\section{Isolation and identification of SF}

Prochaska and coworkers in the late 1980s developed a cell-culture system (known as the Prochaska assay) for the detection of inducers of phase 2 enzymes based on the induction of $\mathrm{NAD}(\mathrm{P}) \mathrm{H}$ :quinone oxidoreductase 1 (NQO1) in murine hepatoma Hepa 1c1c7 cells grown in microtiter plates $^{[11,12]}$. These researchers then used the assay to screen organic solvent extracts of a broad collection of fruit and vegetables for activities involved in the induction of phase 2 enzymes. This was an important effort because it was recognized that the induction of phase 2 enzymes, such as NQO1 and glutathione S-transferase (GST), is an important strategy for achieving protection against carcinogenesis ${ }^{[13,14]}$ and that consumption of fruit and vegetables reduces cancer risk $^{[15]}$. They found that many extracts exhibited significant inducer activities, but the broccoli extract was one of the richest sources of inducer activity ${ }^{[16]}$. In an attempt to identify the inducer(s) in broccoli, we subjected the extracts to multiple runs of fractionation by high performance liquid chromatography and examined each fraction for inducer activity using the Prochaska assay. We succeeded in isolating a liquid substance that was responsible for more than $80 \%$ of the total inducer activity in broccoli extracts. This substance was soon identified as SF (1-isothiocyanato-4(methylsulfinyl)-butane) (Table 1). Approximately $9 \mathrm{mg}$ of SF was isolated from the extracts representing $640 \mathrm{~g}$ fresh broccoli florets; however, it became clear later that the actual amount of SF in the extracts was approximately 10 -fold more ${ }^{[17]}$. Laboratory synthesis of SF provided a sufficient quantity 
Table 1. SF analogs: relation of structure to inducer activity

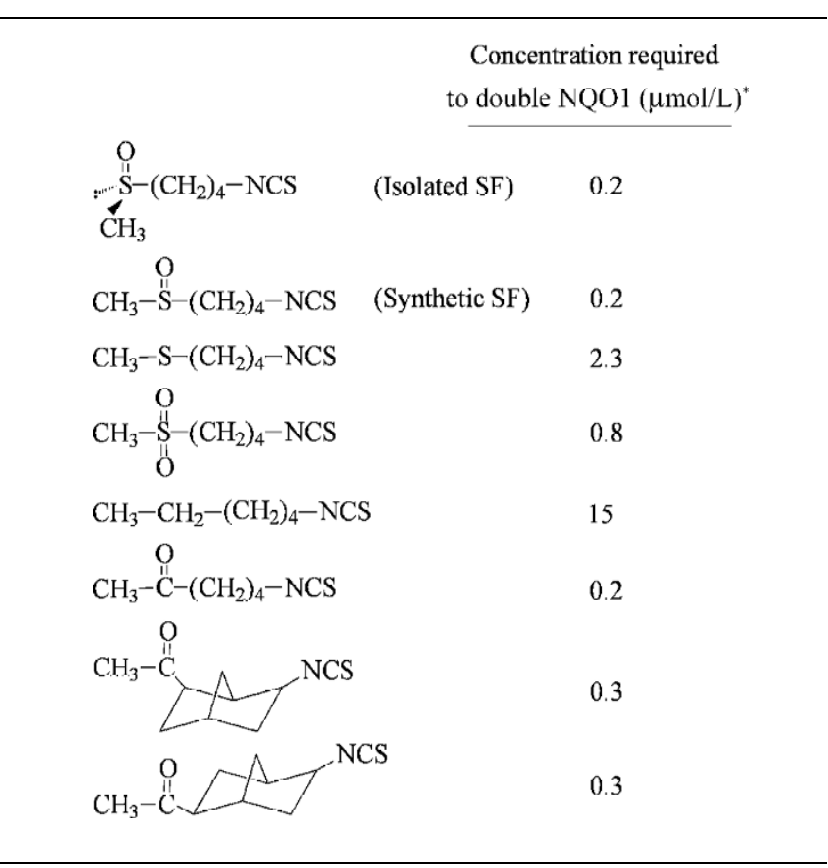

*Conentration of the test compound required to double the NQO1 activity in a standard Prochaska assay in which cells were exposed to the compound for $48 \mathrm{~h}$.

for evaluation in animals, and SF was shown to significantly induce both NQO1 and GST in multiple organs of mice after oral dosing ${ }^{[18]}$. Interestingly, a literature search revealed that SF had already been isolated more than 30 years earlier from hoary cress (a cruciferous weed) for its antimicrobial activity ${ }^{[19,20]}$, and a recent article reports that SF occurs in a wide variety of plants ${ }^{[21]}$. We also became aware at this time that SF was one of a large number of naturally occurring isothiocyanates (ITC) ${ }^{[22]}$, and several ITC had previously been shown to inhibit carcinogenesis in animal experiments ${ }^{[23]}$.

\section{SF analogs: relationship between structure and inducer activity}

In an attempt to ascertain the structural features of SF and in the hope of generating a more potent inducer of phase 2 enzymes, more than 40 analogs of SF were synthesized and evaluated using the Prochaska assay (see Table 1 for representative analogs $)^{[18,24]}$. SF isolated from broccoli is chiral, possessing the R configuration, but both R-SF and the synthetic (R,S)-SF show identical inducer potency. Change of the oxidation state of the sulfur atom in the methylthiol group from sulfoxide to sulfone reduced inducer activity 4-fold, and the sulfide analog was more than 10-fold less active.
Moreover, if the sulfoxide group was replaced with the methylene group, the inducer activity was reduced 75-fold. However, the sulfoxide group could be replaced with a carbonyl group without losing any inducer activity. A change in the number of methylene units from 4 to 5 or 3 did not significantly affect inducer activity (results not shown), nor did the rigidity of the methylene bridge have much effect on inducer activity, as shown by the finding that the norbonyl ITC were almost equally active (Table 1). Although these findings shed new light on the importance of SF structure, we were unable to generate a more potent inducer of phase 2 enzymes than SF. Other investigators reported that converting the $-\mathrm{N}=\mathrm{C}=\mathrm{S}$ of $\mathrm{SF}$ to various dithiocarbamate structures (-NH-CS-SR, R representing various alkyl groups) did not generate a more potent inducer either ${ }^{[25,26]}$.

\section{Identification of edible plants or plant extracts as carriers of SF}

Subsequent studies in our laboratory showed that SF was derived largely, if not entirely, from glucoraphanin, a glucosinolate ( $\beta$-thioglucoside $N$-hydroxysulfate) (Figure 1 ), and that the conversion occurred during the preparation of broccoli extracts ${ }^{[17]}$. This is not unexpected, however, because ITC are known to be synthesized and stored as glucosinolates in plants and are released when damage to plant tissues occurs. The conversion is catalyzed by myrosinase (thioglucoside glucohydrolase), an enzyme that coexists with, but is physically separated from, glucosinolates in normal plants $^{[22]}$. Glucosinolates, including glucoraphanin, which escape the plant myrosinase, can be partially (up to $45 \%$ )
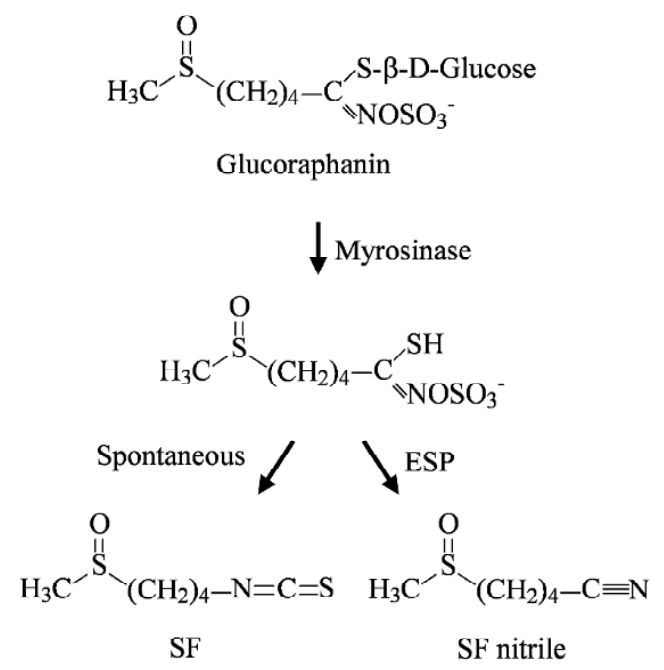

Figure 1. Enzymatic hydrolysis of glucoraphanin. ESP, epithiospecifier protein. 
hydrolyzed in the intestinal tract because the enteric microflora are known to possess myrosinase activity ${ }^{[27-30]}$. However, the following observations indicate that it is extremely difficult to estimate human exposure to dietary SF: (1) our studies revealed that SF yield in different samples of broccoli (both frozen and fresh) sold in supermarkets might differ by as much as 9-fold, and this difference is unrelated to their physical appearance or whether grown under conventional or organic conditions ${ }^{[17]}$, thus, making it impossible to know how much glucoraphanin is present in a particular vegetable without actually measuring it; (2) different cooking conditions are likely to exacerbate variations in SF yield, as steaming or boiling vegetables will reduce the conversion of glucoraphanin to SF by inactivating myrosinase and destroying SF (SF is heat-labile) ${ }^{[31]}$; (3) certain plants including broccoli possess epithiospecifier protein (ESP), which binds to and converts the intermediate of glucoraphanin hydrolysis (a thiohydroximate- $O$-sulfonate) to a nitrile at the expense of SF (Figure 1), but mild heating of broccoli $\left(60-70{ }^{\circ} \mathrm{C}\right)$ inactivated ESP and preserved myrosinase and increased SF yield 3-7-fold ${ }^{[32]}$; and (4) although glucoraphanin not hydrolyzed by vegetable myrosinase could be converted to SF in vivo by the enzyme in the enteric microflora, the growth condition of the microflora significantly affects the hydrolysis ${ }^{[28]}$ and glucosinolate hydrolysis in humans appears to differ by as much as $44-$ fold $^{[33]}$.

Interestingly, our research also suggests that all glucosinolates in mature broccoli might already have been synthesized in the seeds. Thus, there was approximately 15-fold more glucoraphanin in 3-d-old broccoli sprouts ( $c v$ Saga) than in the florets of mature cultiva ${ }^{[17]}$. In addition to glucoraphanin, broccoli sprouts also contain two minor glucosinolates that give rise to two ITC (erucin and iberin) that closely resemble SF in both chemical structure and bioactivity $^{[18,34]}$. Although Faulkner and coworkers report that glucoraphanin content in mature broccoli could be increased 10-fold by crossing broccoli cultivars with selected wild taxa of the Brassica oleracea ${ }^{[35]}$, exploitation of broccoli sprouts may offer an advantage. Investigations have revealed that although indole glucosinolates (4-hydroxyglucobrassin, glucobrassicin and neoglucobrassicin) comprised $68 \%$ of the total in mature broccoli ( $c v$ Saga), this proportion fell to 3\% in the sprouts ${ }^{[17]}$. Similar results were obtained in sprouts grown from other varieties of broccoli seeds ${ }^{[36]}$. Hydrolysis of indole glucosinolates by myrosinase yields highly unstable ITC that spontaneously decompose to compounds such as indole-3-carbinol, indole-3-acetonitrile and 3,3'diindolylmethane, which may have undesired bioactivities $^{[37,38]}$.
We further demonstrated that aqueous extracts of broccoli sprouts were an excellent vehicle for delivering the chemopreventive activity of SF. Feeding rats with broccoli sprout extracts in which the glucosinolates either remained intact or were fully converted to ITC resulted in marked inhibition of mammary tumor development in 7,12-dimethylbenz (a)anthracene-treated female Sprague-Dawley rats ${ }^{[17]}$, and the chemoprevention efficacy of the extracts was comparable to that of pure SF at similar dose levels ${ }^{[39]}$. The anticarcinogenic activity of glucosinolate-containing extracts is likely to result from the conversion of the glucosinolates to ITC in vivo, as studies have shown that intact glucoraphanin does not possess significant chemopreventive activity ${ }^{[17,34]}$, and blocking the conversion of glucosinolates to ITC in broccoli sprout extracts abolishes the chemopreventive activity of the extracts ${ }^{[34]}$. The chemopreventive activity of broccoli sprout extracts has also been demonstrated in other studies $^{[40,41]}$.

\section{Chemopreventive mechanism of SF: more than the induction of phase 2 enzymes}

Activation of nuclear factor erythroid 2-related factor 2 (Nrf2) and Nrf2 target genes Although SF was isolated from broccoli on the basis of NQO1 induction in cultured Hepa 1c1c7 cells (the Prochaska assay), subsequent studies have revealed that it was capable of inducing a large number of phase 2 genes, including epoxide hydrolase ${ }^{[42,43]}$, ferri$\operatorname{tin}^{[43]}$, glutamate cysteine synthetase ${ }^{[42-44]}$, glutathione peroxidase $^{[43,45]}$, glutathione reductase ${ }^{[43,45]}, \mathrm{GST}^{[18,42]}$, heme oxygenase- $1^{[43,45,46]}$, thioredoxin and thioredoxin reductase ${ }^{[43,47,48]}$ and UDP-glucuronosyltransferase $1 \mathrm{~A}^{[49,50]}$ in cultured cells or rodent tissues in vivo. Thus, SF may significantly strengthen cytoprotection because these genes are involved in various aspects of cellular defense against carcinogens and other toxicities. Extensive mechanistic studies have shown that the Kelch-like ECH-associated protein 1 (Keap1)-Nrf2anti-oxidant response element (ARE) signaling pathway is primarily responsible for the coordinate response of these genes to SF. Studies show that the phase 2 genes carry in their 5'-flanking region one or more cis-acting DNA regulatory elements, known as ARE, and activation of ARE leads to coordinate induction of these genes ${ }^{[51]}$. Nrf2 is the key ARE activator, which is normally bound by its repressor Keap1 in the cytoplasm and targeted for proteosomal degradation, but dissociates from the latter in response to an inducer or other signals. Free Nrf2 translocates to the nucleus, complexes with other nuclear factors (eg small Maf) and binds to ARE to activate the transcription of the down- 
stream gene ${ }^{[52]}$. SF was shown to activate Nrf2 by directly reacting with the sulfhydryl groups of critical cysteine residues of Keap $1^{[53]}$, although a recent study found that modifying specific cysteines of Keap1 might be insufficient for Nrf2 activation ${ }^{[54]}$ and other studies implicated the mitogenactivated protein kinase pathway in Nrf2 activation by $\mathrm{SF}^{[55,56]}$. Nrf2 knockout rendered phase 2 genes largely unresponsive to $\mathrm{SF}^{[42,43]}$ and two mouse studies have shown that $\mathrm{Nrf} 2$ knockout not only increased the susceptibility of the animals to chemical carcinogenesis but also abolished the ability of SF to inhibit carcinogenesis ${ }^{[57,58]}$. Interestingly, genearray studies revealed that SF also upregulated a large number of non-phase- 2 genes, and the response of some of these genes to SF also depended on the Keap1-Nrf2-ARE pathway $^{[42,43,59]}$.

Modulation of cytochrome P-450 enzymes In addition to inducing phase 2 enzymes, several studies have also shown that SF modulates certain cytochrome P-450 (CYP) enzymes (phase 1 enzymes). CYP enzymes are important for normal metabolic processing of numerous endogenous and exogenous compounds, but may also activate certain carcinogens. For example, CYP2E1 causes the activation of carcinogens such as $N$-nitrosodimethylamine ${ }^{[60,61]}$ and CYP1A2 activates 2-amino-1-methyl-6-phenylimidazo(4,5-b) pyridine (PhIP) ${ }^{[62]}$. SF was shown to inhibit the catalytic activity of a number of CYP enzymes, including CYP1A1, $1 \mathrm{~A} 2,2 \mathrm{~B} 1 / 2,2 \mathrm{E} 1$ and $3 \mathrm{~A} 4^{[60,61,63-66]}$, and to downregulate CYP3A4 in hepatocytes ${ }^{[64]}$. However, feeding rats with SF elevated CYP1A2 expression ${ }^{[65]}$ and feeding rats with glucoraphanin (the SF precursor) elevated CYP1A1, 1A2, $2 \mathrm{~B} 1 / 2,2 \mathrm{C} 11$ and $3 \mathrm{~A} 1$ in the lungs ${ }^{[67]}$. Hence, it remains unclear if CYP enzymes are relevant targets in SF chemoprevention.

Induction of apoptosis and inhibition of proliferation Induction of apoptosis and inhibition of proliferation are important mechanisms for the inhibition of carcinogenesis and cancer growth. In addition to acting as an inducer of phase 2 genes, numerous studies have also documented the ability of SF to induce apoptosis and cell cycle arrest in cancer cell lines derived from bladder ${ }^{[68,69]}$, blood ${ }^{[70,71]}$, brain $^{[72]}$, breast ${ }^{[73]}$, colon ${ }^{[74,75]}$, ovary ${ }^{[76]}$, pancreas $^{[77]}$, prostate $^{[78,79]}$ and skin ${ }^{[80]}$, indicating that this activity is not cell specific. SF also inhibited the growth of human cancer xenografts in mice in vivo and tumor tissues of SF-treated mice showed increased apoptosis ${ }^{[77,79]}$. SF has been shown to activate several programmed cell death mechanisms, including mitochondria-mediated apoptosis ${ }^{[74,81]}$, death-receptormediated apoptosis ${ }^{[82-84]}$ and autophagic cell death ${ }^{[85]}$, and to arrest cells in G1 phase ${ }^{[69,78,86]}, \mathrm{S}$ phase ${ }^{[68]}$ and/or G2/M phase ${ }^{[68,77,87,88]}$, depending on the cell line under study. Moreover, these and other studies have shown that these actions of SF are associated with the modulation of many regulators of cell death and cell cycle, including activation of mitogen-activated protein kinases, modulation of Bcl-2 family proteins, damage of mitochondria and release of apoptogenic factors from mitochondria, activation of caspases, modulation of cyclins and cdks, downregulation of $\mathrm{Cdc} 25 \mathrm{C}$, upregulation of $\mathrm{p} 21$, inhibition of histone deacetylase and tubulin polymerization ${ }^{[10,68,79,81,88-93]}$. The anticancer activity of SF does not depend on p53 because SF induced apoptosis in wild-type p53-, mutated p53- and p53 knockout fibroblasts ${ }^{[94]}$, induced autophagy in both human prostate cancer PC-3 cells (p53-deficient) and LNCaP cells (p53-normal) ${ }^{[85]}$, and induced G1 arrest in human colon cancer HT-29 cells in a p53-independent manner ${ }^{[95]}$. SF may also potentiate other anticancer agents because it has been shown to enhance the efficacy of doxorubicin and reverse doxorubicin-resistant phenotype in mouse fibroblasts with p53 mutation ${ }^{[96,97]}$.

Inhibition of angiogenesis and metastasis More recent studies demonstrate that SF is also capable of inhibiting angiogenesis and metastasis. Using immortalized human microvascular endothelial HMEC-1 cells, SF was shown to potently reduce in vitro formation of microcapillaries, suppress capillary-like tube formation on basement membrane matrix and inhibit cell migration ${ }^{[98]}$. These effects were not due to inhibition of cell proliferation, but were associated with transcriptional downregulation of factors important for tumor angiogenesis and metastasis, including vascular endothelial growth factor (VEGF) and its receptor KDR/flk-1, hypoxia-inducible factor-1 $\alpha$ (Hif- $1 \alpha$ ), c-Myc and matrix metalloproteinase (MMP)-2. SF also inhibited the proliferation and tubular formation on matrigel of human umbilical vein endothelial cells in vitro ${ }^{[99]}$, and was responsible for inhibition of MMP-9 activity and invasiveness of human breast cancer MDA-MB-231 cells by broccoli extracts ${ }^{[100]}$. Both MMP-2 and MMP-9 play an important role in cancer cell invasion ${ }^{[101]}$. Inhibition of angiogenesis and metastasis by SF was also demonstrated in vivo. Intravenous administration of non-toxic doses of SF inhibited endothelial cell response to VEGF in a subcutaneous VEGF-impregnated matrigel plug mouse model ${ }^{[102]}$. Moreover, although intravenous injection of B16F-10 melanoma cells into C57BL/6 mice led to formation of lung tumor nodules, SF administered intraperitoneally at very low dose $(0.5 \mathrm{mg} / \mathrm{kg}$ body weight $)$ markedly inhibited lung tumor nodule formation ${ }^{[103]}$. The potent inhibitory effect of SF observed in this model did not appear to result from a cytotoxic effect of SF on B16F-10 
cells, but was associated with inhibition of MMP activation.

Other mechanisms of SF that may also contribute to its anticarcinogenic and anticancer activity SF treatment significantly enhanced natural killer (NK) cell activity and antibody-dependent cellular cytotoxicity in both normal and Ehrlich ascites tumor-bearing mice, which was accompanied by increased proliferation of bone marrow cells, splenocytes and thymocytes, as well as increased production of interleukin-2 and interferon- $\gamma^{[104]}$. Treatment of Raw 264.7 murine macrophages with SF resulted in the inhibition of lipopolysaccharide (LPS)-induced secretion of pro-inflammatory and procarcinogenic signaling molecules, including nitric oxide, prostaglandin $E_{2}$ and tumor necrosis factor- $\alpha$, and nuclear factor-kappa B (NF- $\kappa \mathrm{B}$ ) was shown to be the molecular target of $\mathrm{SF}^{[105]}$. SF also inhibited diesel-extract-induced production of pro-inflammation cytokins in primary human bronchial epithelial cells ${ }^{[106]}$. Further studies in human prostate cancer PC-3 cells showed that suppression of NF- $\kappa B$ and $\mathrm{NF}-\kappa \mathrm{B}-$ regulated gene expression involved inhibition of IkB kinases (IKK) and $\mathrm{I} \kappa \mathrm{B} \alpha$ as well as inhibition of nuclear translocation of $\mathrm{p} 65^{[107]}$. $\mathrm{O}^{6}$-methylguanine-DNA methyltransferase (MGMT) is a DNA repair protein that protects the genome against the mutagenic action of alkylating carcinogens, such as 4-(methylnitrosamino)-1-(3-pyridyl)-1-butanone (NNK) and nitrosamines. Treatment of human medulloblastoma UW228 cells and human colon carcinoma HT29 cells with SF significantly increased MGMT activity ${ }^{[108]}$. Ornithine decarboxylase (ODC) is a rate-limiting enzyme in polyamine biosynthesis, and increased expression of ODC is linked to tumor promotion. SF was shown to inhibit 12-Otetradecanoylphorbol-13-acetate (TPA)-induced ODC activity in mouse epidermal ME308 cells ${ }^{[109]}$. SF was also shown to significantly induce the expression of multidrug-resistance-associated protein 2 (MRP2) in primary hepatocytes and Caco- 2 cells ${ }^{[75,110]}$, although it did not impact on MRP1 and P-glycoprotein ${ }^{[111]}$. Increased expression of MRP2 may increase cellular protection against toxic chemicals. Moreover, the antimicrobial activity of SF has long been recognized $^{[20]}$ and SF was recently shown to be effective against Helicobacter pylori, a significant risk factor for gastric can$\operatorname{cer}^{[57,112]}$.

\section{Preclinical and clinical evaluation of the in vivo efficacy of SF}

Preclinical A variety of rodent models have been used to assess the in vivo efficacy of SF, some of which have been mentioned above. SF was shown to significantly inhibit tumor development induced by a number of chemical carcinogens in several rodent organ sites, including colon ${ }^{[113]}$, lungs ${ }^{[114]}$, mammary ${ }^{[39]}$, pancreas ${ }^{[115]}, \operatorname{skin}^{[58,116]}$ and stomach ${ }^{[57]}$, and SF was effective when it was given either in the carcinogen initiation phase or in the promotion phase. SF is believed to be responsible for the inhibition of ultraviolet (UV)induced skin carcinogenesis by broccoli sprout extracts, which were applied topically after the completion of UV treatment (during the post-initiation phase) ${ }^{[117]}$. Some of these studies also highlight the importance of phase 2 induction in enabling the chemopreventive activity of SF, especially in the initiation phase, as induction of phase 2 genes in target tissues has been detected in SF-treated animals ${ }^{[26,117]}$, and knockout of Nrf2 abolished the induction of phase 2 genes by $\mathrm{SF}$ and abrogated the chemopreventive activity of $\mathrm{SF}^{[57,58]}$. However, other studies show the importance of other chemopreventive mechanisms of SF. For example, SF administered to $\mathrm{A} / \mathrm{J}$ mice after the completion of a combined treatment of benzo(a)pyrene and NNK inhibited malignant progression of adenoma to adenocarcinoma in the lungs with a corresponding increase in apoptotic cells and a decrease in proliferating cell nuclear antigen expression ${ }^{[114]}$. SF supplemented in the diet significantly inhibited the formation of intestinal polyps in ApcMin/+ mice ${ }^{[18]}$. Tumors in these mice occur spontaneously because of a mutation of the tumor suppressor adenomatous polyposis coli (APC) gene ${ }^{[119]}$. Analysis of polyp tissues from SF-treated mice did not indicate induction of phase 2 genes, but instead showed increased apoptosis and decreased proliferation. Further study of the polyp tissues using a microarray technique showed that SF treatment caused upregulation of multiple proapoptotic genes and downregulation of multiple pro-survival genes $^{[120]}$. The anticancer activity of SF was further demonstrated in experiments where SF dosed either orally or intraperitoneally significantly inhibited the growth of subcutaneous xenografts of human prostate cancer PC-3 cells and human pancreatic cancer PANC-1 cells in mice ${ }^{[77,79]}$, and inhibited lung tumor formation from intravenous injection of B16F-10 melanoma cells in mice ${ }^{[103]}$.

Clinical To the best of our knowledge, SF in pure form has not yet been investigated in humans. However, the discovery of broccoli sprouts as an exceptionally rich source of SF has provided an alternative to examine its potential impact in humans. A placebo-controlled, double-blind, randomized phase 1 study of broccoli sprout extracts, containing either glucosinolate (mainly glucoraphanin) or ITC (mainly $\mathrm{SF}$ ), showed that the extracts were well tolerated and caused no significant adverse effects when the extracts were administered orally at 8-h intervals for $7 \mathrm{~d}$ at doses of 25 and 100 $\mu \mathrm{mol}$ glucosinolate or $25 \mu \mathrm{mol}$ ITC $^{[121]}$. In another random- 
ized and placebo-controlled study involving 200 healthy adults, nightly consumption of hot water infusions of broccoli sprouts containing $400 \mu \mathrm{mol}$ glucoraphanin $(656 \mu \mathrm{mol}$ total glucosinolate) for 2 weeks was also well tolerated and showed no adverse effects ${ }^{[33]}$. Topical application of SF as high as $340 \mathrm{nmol}$ in the form of broccoli sprout extracts to the center of a 1-cm-diameter circle of skin in humans caused no adverse reactions, but NQO1 activity in the skin tissues was elevated 1.5-fold and 4.5-fold after application of $150 \mathrm{nmol}$ SF once or three times, respectively, (at 24 h-intervals) ${ }^{[40]}$.

\section{Metabolism and disposition of SF}

Animal and human studies Many lines of evidence indicate that SF is rapidly metabolized through the mercapturic acid pathway: initial conjugation with glutathione (GSH) promoted by GST gives rise to the corresponding conjugate, which undergoes sequential enzymatic modifications to form cysteinylglycine, cysteine and $N$-acetylcysteine (NAC) conjugates, which are disposed in urine (Figure 2). Approximately $72 \%$ of a single oral dose of SF was recovered in the urine as NAC conjugates in rats in $24 \mathrm{~h}^{[122]}$, but only about $1 \%$ of the dose was detected in the second $24-\mathrm{h}$ urine sample ${ }^{[41]}$, indicating that urinary elimination occurs almost entirely within $24 \mathrm{~h}$ after SF dosing. Similar changes were seen in humans because $58.3 \pm 2.8 \%$ and $77.9 \pm 6.4 \%$ of a single dose of approximately $200 \mu \mathrm{mol}$ ITC (mainly SF) contained in broccoli sprout extracts was recovered in the urine as SF equivalents in $8 \mathrm{~h}$ and $72 \mathrm{~h}$, respectively, although the levels of free $\mathrm{SF}$ and individual metabolite were not determined ${ }^{[123]}$. These results also show that the bioavailability of SF is extremely high and inter-individual variation of SF absorption and
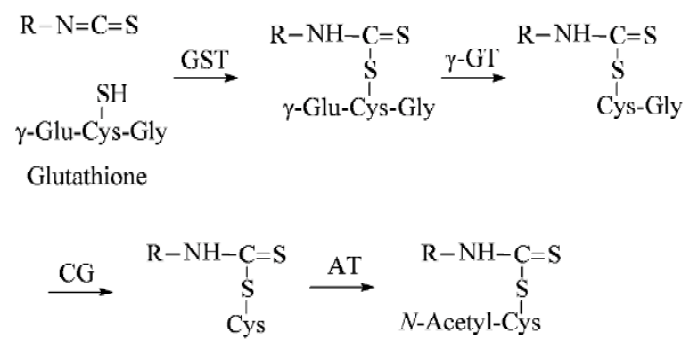

Figure 2. Metabolism of $\mathrm{SF}$ through the mercapturic acid pathway. The chemical structure of $\mathrm{SF}$ is abbreviated as $\mathrm{R}-\mathrm{N}=\mathrm{C}=\mathrm{S}$, where $\mathrm{R}$ represents $\mathrm{CH}_{3}-\mathrm{SO}-\left(\mathrm{CH}_{2}\right)_{4}$. SF first reacts with glutathione to give rise to a glutathione-SF conjugate, which is promoted by glutathione S-transferase (GST). The conjugate undergoes further enzymatic modification as shown, first by $\gamma$-glutamyltranspeptidase $(\gamma-\mathrm{GT})$ to form the cysteinylglycine-SF conjugate, then by cysteinylglycinase (CG) to form the cysteine-SF conjugate and finally by $N$ acetyltransferase (AT) to form the $N$-acetylcysteine-SF conjugate. metabolism is small. Moreover, the urinary SF elimination pattern was not significantly altered even after repeated SF dosing (oral broccoli sprout extracts containing $25 \mu \mathrm{mol}$ ITC at 8-h intervals for $7 \mathrm{~d})^{[121]}$. The rapid urinary elimination of $\mathrm{SF}$ is closely correlated with its rapid absorption ${ }^{[124]}$ and short plasma half-life because plasma concentrations of SF equivalents peaked $(0.94-2.27 \mu \mathrm{mol} / \mathrm{L}) 1 \mathrm{~h}$ after feeding the extracts in the afore-described human experiment (single dose of approximately $200 \mu \mathrm{mol}$ ITC) and declined with first-order kinetics (half-life $1.77 \pm 0.13 \mathrm{~h}$ ). Similar results were seen in other studies in which human subjects were given a single dose of mature broccoli soup ${ }^{[125,126]}$. These studies also revealed that free SF and its cysteine conjugate were more abundant than the other conjugates in the plasma and that significant quantities of free SF and cysteine conjugate were present in the urine in addition to the NAC conjugate. It is important to note that the thiol conjugates of SF as well as those of other ITC serve as carriers of ITC ${ }^{[127]}$, and SF-NAC has been shown to exhibit equally if not more potent chemopreventive activities in comparison with $\mathrm{SF}^{[78,114,128,129]}$.

Cell culture studies Studies in cultured cells in our laboratory have provided an explanation for the rapid absorption and elimination of SF observed in vivo. We have shown that SF as well as other ITC are rapidly accumulated in cells, but that the accumulated ITC equivalents are rapidly exported ${ }^{[130-134]}$ (Figure 3). ITC appear to penetrate cells by diffusion, but the ITC upon entering the cells is rapidly conjugated with intracellular thiols. GSH, which is the most abundant intracellular thiol, is the major driving force for ITC accumulation, and cellular GST enhances ITC accumulation by promoting the conjugation reaction. Not surprisingly, ITC that are already conjugated with thiols are unable to accumulate in cells $^{[131]}$. It has been shown that peak intracellular ITC accumulation is achieved within $0.5-3 \mathrm{~h}$ after exposure, reaching 100-200-fold over the extracellular ITC concentration, and the peak intracellular ITC accumulation levels can reach the millimolar concentration range. However, intracellularly accumulated GSH conjugates of ITC, perhaps other conjugates as well, were also exported rapidly, and this appears to be mediated at least, in part, by membrane transporter MRP1 $1^{[133,}$ ${ }^{134]}$. For example, the half-life of the accumulated SF equivalent in human prostate cancer LNCaP cells was only about 1 h. Thus, continuous intracellular accumulation seems to be possible only if there is a continuous presence of ITC in the extracellular space to allow continuous cellular uptake of ITC to offset the rapid export of accumulated ITC conjugates.

\section{Conclusion and future perspectives}

Since SF was reported to be the principle inducer of phase 


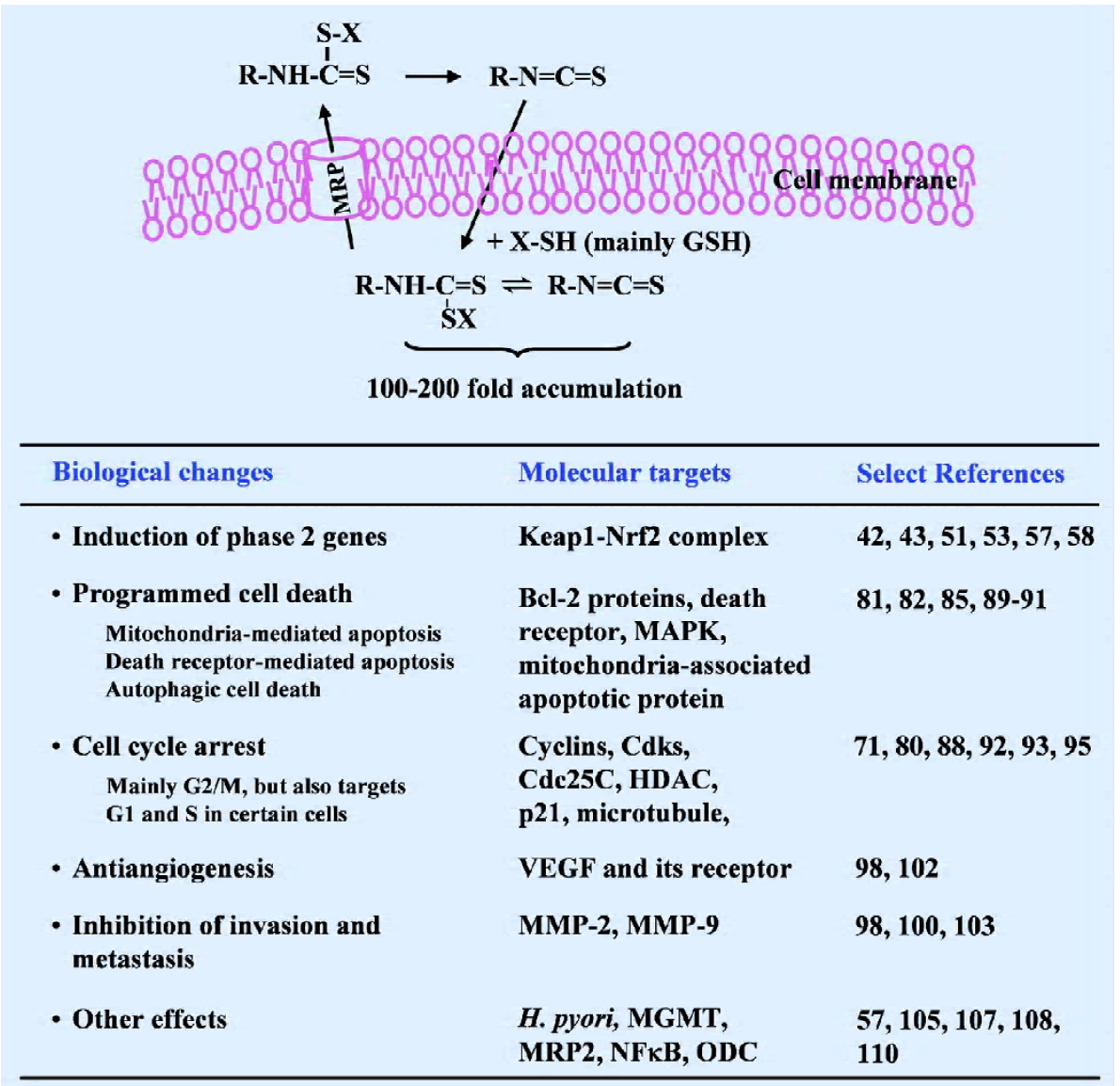

Figure 3. Cellular accumulation and export of SF and its chemopreventive mechanism. The chemical structure of SF is abbreviated as $\mathrm{R}-$ $\mathrm{N}=\mathrm{C}=\mathrm{S}$, where $\mathrm{R}$ represents $\mathrm{CH}_{3}-\mathrm{SO}-\left(\mathrm{CH}_{2}\right)_{4}$. Cdc25C, cell division cycle 25C; HDAC, histone deacetylase; Keap1, Kelch-like ECH-associated protein 1; MAPK, mitogen-activated protein kinase; MMP, matrix metalloproteinase; MGMT, $\mathrm{O}^{6}$-methylguanine-DNA methyltransferase; MRP2, multidrug-resistance-associated protein 2; NF- $\mathrm{BB}$, nuclear factor-kappa B; Nrf2, nuclear factor erythroid 2-related factor 2; ODC, ornithine decarboxylase; VEGF, vascular endothelial growth factor; X-SH, X stands for the side chain of a sulfhydryl molecule.

2 enzymes in broccoli in 1992, extensive studies of this compound have followed, which reveal that SF is a highly promising agent for cancer prevention and perhaps also useful in cancer therapy. A summary of its cellular uptake and molecular mechanisms is provided in Figure 3. Given the widespread interest in SF, our understanding about its mechanism as well as its bioactivity will undoubtedly become more sophisticated. Broccoli sprout extracts are an excellent vehicle for SF delivery and have allowed for human evaluation of SF in the absence of the approved use of pure SF. In fact, we are aware that more human trials with this substance are either ongoing or are to be initiated in the near future. These studies will not only address the utility of broccoli sprout extracts for cancer prevention/treatment in humans, but will also provide critical information as to whether the investigation of pure SF in humans is warranted. In addition, it is important to note that a few studies have shown the ability of SF to enhance the efficacy of another anticancer agent. More investigations of this ability of SF should be emphasized to determine whether SF can be used in combination therapy.

\section{References}

1 Tsuda H, Ohshima Y, Nomoto H, Fujita K, Matsuda E, Iigo M, et al. Cancer prevention by natural compounds. Drug Metab Pharmacokinet 2004; 19: 245-63.

2 Park E J, Pezzuto J M. Botanicals in cancer chemoprevention. Cancer Metastasis Rev 2002; 21: 231-55.

3 D'Incalci M, Steward WP, Gescher A J. Use of cancer chemopreventive phytochemicals as antineoplastic agents. Lancet Oncol 2005; 6: 899-904.

4 Dorai T, Aggarwal B B. Role of chemopreventive agents in cancer therapy. Cancer Lett 2004; 215: 129-40.

5 Fimognari C, Hrelia P. Sulforaphane as a promising molecule for fighting cancer. Mutat Res 2007; 635: 90-104. 
6 Myzak MC, Dashwood R H. Chemoprotection by sulforaphane: keep one eye beyond Keap1. Cancer Lett 2006; 233: 208-18.

7 Fahey JW, Talalay P. Antioxidant functions of sulforaphane: a potent inducer of Phase II detoxication enzymes. Food Chem Toxicol 1999, 37: 973-79.

8 Zhang Y. Cancer chemoprevention with sulforaphane, a dietary isothiocyanate. In: Bao Y, Fenwick G R, editors.Phytochemicals in health and disease. New York: Marcel Dekker, 2004. p12141 .

9 Juge N, Mithen R F, Traka M. Molecular basis for chemoprevention by sulforaphane: a comprehensive review. Cell Mol Life Sci 2007; 64: 1105-27.

10 Gamet-Payrastre L. Signaling pathways and intracellular targets of sulforaphane mediating cell cycle arrest and apoptosis. Curr Cancer Drug Targets 2006; 6: 135-45.

11 Prochaska HJ, Santamaria AB. Direct measurement of NAD(P) $\mathrm{H}$ :quinone reductase from cells cultured in microtiter wells: a screening assay for anticarcinogenic enzyme inducers. Anal Biochem 1988; 169: 328-36.

12 Fahey JW, Dinkova-Kostova AT, Stephenson KK, Talalay P. The "Prochaska" microtiter plate bioassay for inducers of NQO1. Methods Enzymol 2004; 382: 243-58.

13 Talalay P. Chemoprotection against cancer by induction of phase 2 enzymes. Biofactors 2000; 12: 5-11.

14 Talalay P. Mechanisms of induction of enzymes that protect against chemical carcinogenesis. Adv Enzyme Regul 1989;28: 237-50.

15 IARC handbooks of cancer prevention. Vol 8. Fruit and vegetables. Vainio H, Bianchini F, editors. Lyon: IARC Press, 2003.

16 Prochaska HJ, Santamaria AB, Talalay P. Rapid detection of inducers of enzymes that protect against carcinogens. Proc Natl Acad Sci USA 1992; 89: 2394-8.

17 Fahey JW, Zhang Y, Talalay P. Broccoli sprouts: an exceptionally rich source of inducers of enzymes that protect against chemical carcinogens. Proc Natl Acad Sci USA 1997; 94: 1036772 .

18 Zhang Y, Talalay P, Cho CG, Posner GH. A major inducer of anticarcinogenic protective enzymes from broccoli: isolation and elucidation of structure. Proc Natl Acad Sci U S A, 1992; 89: 2399-403.

19 Procháska Z. Isolation of sulforaphane from hoary cress (Lepidium draba L.). Collect Czech Chem Commun 1959; 24: 2429-30.

20 Procháska Z, Komersová I. Isolation of sulforaphane from Cardaria draba and its antimicrobial effect. Cesk Farm 1995; 8: 373-6.

21 Fahey JW, Zalcmann AT, Talalay P. The chemical diversity and distribution of glucosinolates and isothiocyanates among plants. Phytochemistry 2001; 56: 5-51.

22 Fenwick GR, Heaney RK, Mullin WJ. Glucosinolates and their breakdown products in food and food plants. Crit Rev Food Sci Nutr 1983; 18: 123-201.

23 Zhang Y, Talalay P. Anticarcinogenic activities of organic isothiocyanates: chemistry and mechanisms. Cancer Res 1994; 54: $1976 \mathrm{~s}-81 \mathrm{~s}$.

24 Posner GH, Cho CG, Green JV, Zhang Y, Talalay P. Design and synthesis of bifunctional isothiocyanate analogs of sulforaphane: correlation between structure and potency as inducers of anticarcinogenic detoxication enzymes. J Med Chem 1994; 37 : $170-6$.

25 Moriarty RM, Naithani R, Kosmeder J, Prakash O. Cancer chemopreventive activity of sulforamate derivatives. Eur J Med Chem 2006; 41: 121-4.

26 Gerhauser C, You M, Liu J, Moriarty RM, Hawthorne M, Mehta $\mathrm{RG}$, et al. Cancer chemopreventive potential of sulforamate, a novel analogue of sulforaphane that induces phase 2 drug-metabolizing enzymes. Cancer Res 1997; 57: 272-8.

27 Rabot S, Nugon-Baudon L, Raibaud P, Szylit O. Rape-seed meal toxicity in gnotobiotic rats: influence of a whole human faecal flora or single human strains of Escherichia coli and Bacteroides vulgatus. Br J Nutr 1993; 70: 323-31.

28 Shapiro TA, Fahey JW, Wade KL, Stephenson KK, Talalay P. Human metabolism and excretion of cancer chemoprotective glucosinolates and isothiocyanates of cruciferous vegetables. Cancer Epidemiol Biomarkers Prev 1998; 7: 1091-100.

29 Getahun SM, Chung FL. Conversion of glucosinolates to isothiocyanates in humans after ingestion of cooked watercress. Cancer Epidemiol Biomarkers Prev 1999; 8: 447-51.

30 Bheemreddy RM, Jeffery EH. The Metabolic Fate of Purified Glucoraphanin in F344 Rats. J Agric Food Chem 2007; 55: 2861-6.

31 Jin Y, Wang M, Rosen RT, Ho CT. Thermal degradation of sulforaphane in aqueous solution. J Agric Food Chem 1999; 47: 3121-3.

32 Matusheski NV, Juvik JA, Jeffery EH. Heating decreases epithiospecifier protein activity and increases sulforaphane formation in broccoli. Phytochemistry 2004; 65: 1273-81.

33 Kensler TW, Chen JG, Egner PA, Fahey JW, Jacobson LP, Stephenson, KK, et al. Effects of glucosinolate-rich broccoli sprouts on urinary levels of aflatoxin-DNA adducts and phenanthrene tetraols in a randomized clinical trial in He Zuo township, Qidong, People's Republic of China. Cancer Epidemiol Biomarkers Prev 2005; 14: 2605-13.

34 Tang L, Zhang Y, Jobson HE, Li J, Stephenson KK, Wade KL, et al. Potent activation of mitochondria-mediated apoptosis and arrest in $\mathrm{S}$ and $\mathrm{M}$ phases of cancer cells by a broccoli sprout extract. Mol Cancer Ther 2006; 5: 935-44.

35 Faulkner K, Mithen R, Williamson G. Selective increase of the potential anticarcinogen 4-methylsulphinylbutyl glucosinolate in broccoli. Carcinogenesis 1998; 19: 605-9.

36 Shapiro TA, Fahey JW, Wade KL, Stephenson KK, Talalay P. Chemoprotective glucosinolates and isothiocyanates of broccoli sprouts: metabolism and excretion in humans. Cancer Epidemiol Biomarkers Prev 2001; 10: 501-8.

37 Kim D J, Han BS, Ahn B, Hasegawa R, Shirai T, Ito N, et al. Enhancement by indole-3-carbinol of liver and thyroid gland neoplastic development in a rat medium-term multiorgan carcinogenesis model. Carcinogenesis 1997; 18: 377-81.

38 Bjeldanes LF, Kim JY, Grose KR, Bartholomew JC, Bradfield CA. Aromatic hydrocarbon responsiveness-receptor agonists generated from indole-3-carbinol in vitro and in vivo: comparisons with 2,3,7,8-tetrachlorodibenzo-p-dioxin. Proc Natl Acad Sci USA 1991; 88: 9543-7.

39 Zhang Y, Kensler TW, Cho CG, Posner GH, Talalay P. Anticarcinogenic activities of sulforaphane and structurally re- 
lated synthetic norbornyl isothiocyanates. Proc Natl Acad Sci USA 1994; $91:$ 3147-50.

40 Dinkova-Kostova AT, Fahey JW, Wade KL, Jenkins SN, Shapiro TA, Fuchs EJ, et al. Induction of the Phase 2 Response in Mouse and Human Skin by Sulforaphane-containing Broccoli Sprout Extracts. Cancer Epidemiol Biomarkers Prev 2007; 16 : 847-51.

41 Zhang Y, Munday R, Jobson HE, Munday CM, Lister C, Wilson $\mathrm{P}$, et al. Induction of GST and NQO1 in cultured bladder cells and in the urinary bladders of rats by an extract of broccoli (Brassica oleracea italica) sprouts. J Agric Food Chem 2006; 54: 9370-6.

42 Thimmulappa RK, Mai KH, Srisuma S, Kensler TW, Yamamoto $\mathrm{M}$, Biswal S. Identification of Nrf2-regulated genes induced by the chemopreventive agent sulforaphane by oligonucleotide microarray. Cancer Res 2002; 62: 5196-203.

$43 \mathrm{Hu}$ R, Xu C, Shen G, Jain MR, Khor TO, Gopalkrishnan A, et al. Gene expression profiles induced by cancer chemopreventive isothiocyanate sulforaphane in the liver of C57BL/6J mice and C57BL/6J/Nrf2 (-/-) mice. Cancer Lett 2006; 243: 170-192.

44 Zhang Y, Gonzalez V, Xu MJ. Expression and regulation of glutathione S-transferase P1-1 in cultured human epidermal cells. J Dermatol Sci 2002; 30: 205-14.

$45 \mathrm{Wu}$ L, Juurlink BH. The impaired glutathione system and its upregulation by sulforaphane in vascular smooth muscle cells from spontaneously hypertensive rats. J Hypertens 2001; 19: 181925.

46 Cornblatt BS, Ye L, Dinkova-Kostova AT, Erb M, Fahey JW, Singh NK, et al. Preclinical and Clinical Evaluation of Sulforaphane for Chemoprevention in the Breast. Carcinogenesis 2007; 28: 1485-90.

47 Bacon JR, Plumb GW, Howie A F, Beckett G J, Wang W, Bao Y. Dual action of sulforaphane in the regulation of thioredoxin reductase and thioredoxin in human HepG2 and Caco-2 cells. J Agric Food Chem 2007; 55: 1170-6.

48 Wang W, Wang S, Howie AF, Beckett GJ, Mithen R, Bao Y. Sulforaphane, erucin, and iberin up-regulate thioredoxin reductase 1 expression in human MCF-7 cells. J Agric Food Chem 2005; 53: 1417-21.

49 Basten GP, Bao Y, Williamson G. Sulforaphane and its glutathione conjugate but not sulforaphane nitrile induce UDPglucuronosyl transferase (UGT1A1) and glutathione transferase (GSTA1) in cultured cells. Carcinogenesis 2002; 23: 1399-404.

50 Wang M, Li YQ, Zhong N, Chen J, Xu XQ, Yuan MB. Induction of uridine 5'-diphosphate-glucuronosyltransferase gene expression by sulforaphane and its mechanism: experimental study in human colon cancel cells. Zhonghua Yi Xue Za Zhi 2005; 85 : 819-24. Chinese.

51 Zhang Y, Gordon GB. A strategy for cancer prevention: stimulation of the Nrf2-ARE signaling pathway. Mol Cancer Ther 2004; 3: 885-93.

52 Dinkova-Kostova AT, Holtzclaw WD, Kensler TW. The role of Keap1 in cellular protective responses. Chem Res Toxicol 2005; 18: 1779-91.

53 Dinkova-Kostova AT, Holtzclaw WD, Cole RN, Itoh K, Wakabayashi N, Katoh Y, et al. Direct evidence that sulfhydryl groups of Keap1 are the sensors regulating induction of phase 2 enzymes that protect against carcinogens and oxidants. Proc
Natl Acad Sci USA 2002; 99: 11908-13.

54 Eggler AL, Liu G, Pezzuto JM, van Breemen RB, Mesecar AD. Modifying specific cysteines of the electrophile-sensing human Keap1 protein is insufficient to disrupt binding to the Nrf2 domain Neh2. Proc Natl Acad Sci USA 2005; 102: 10070-5.

55 Yu R, Lei W, Mandlekar S, Weber MJ, Der CJ, Wu J, et al. Role of a mitogen-activated protein kinase pathway in the induction of phase II detoxifying enzymes by chemicals. J Biol Chem 1999; 274: 27545-52.

56 Yu R, Mandlekar S, Lei W, Fahl WE, Tan TH, Kong AN. p38 mitogen-activated protein kinase negatively regulates the induction of phase II drug-metabolizing enzymes that detoxify carcinogens. J Biol Chem 2000; 275: 2322-7.

57 Fahey JW, Haristoy X, Dolan PM, Kensler TW, Scholtus I, Stephenson KK, et al. Sulforaphane inhibits extracellular, intracellular, and antibiotic-resistant strains of Helicobacter pylori and prevents benzo[a]pyrene-induced stomach tumors. Proc Natl Acad Sci USA 2002; 99: 7610-5.

$58 \mathrm{Xu} \mathrm{C}$, Huang MT, Shen G, Yuan X, Lin W, Khor TO, et al. Inhibition of 7,12-Dimethylbenz(a)anthracene-Induced Skin Tumorigenesis in C57BL/6 Mice by Sulforaphane Is Mediated by Nuclear Factor E2-Related Factor 2. Cancer Res 2006; 66: 8293-6.

$59 \mathrm{Hu}$ R, Hebbar V, Kim BR, Chen C, Winnik B, Buckley B, et al. In vivo pharmacokinetics and regulation of gene expression profiles by isothiocyanate sulforaphane in the rat. J Pharmacol Exp Ther 2004; 310: 263-71.

60 Barcelo S, Gardiner JM, Gescher A, Chipman J K. CYP2E1mediated mechanism of anti-genotoxicity of the broccoli constituent sulforaphane. Carcinogenesis 1996; 17: 277-82.

61 Barcelo S, Mace K, Pfeifer AM, Chipman JK. Production of DNA strand breaks by N-nitrosodimethylamine and 2-amino-3methylimidazo[4,5-f]quinoline in THLE cells expressing human CYP isoenzymes and inhibition by sulforaphane. Mutat Res 1998; 402: 111-20.

62 Bacon JR, Williamson G, Garner RC, Lappin G, Langouet S, Bao Y. Sulforaphane and quercetin modulate PhIP-DNA adduct formation in human HepG2 cells and hepatocytes. Carcinogenesis 2003; 24: 1903-11.

63 Conaway CC, Jiao D, Chung FL. Inhibition of rat liver cytochrome $\mathrm{P} 450$ isozymes by isothiocyanates and their conjugates: a structure-activity relationship study. Carcinogenesis 1996; 17: 2423-7.

64 Maheo K, Morel F, Langouet S, Kramer H, Le Ferrec E, Ketterer $\mathrm{B}$, Guillouzo A. Inhibition of cytochromes P-450 and induction of glutathione S-transferases by sulforaphane in primary human and rat hepatocytes. Cancer Res 1997; 57: 3649-3652.

65 Yoxall V, Kentish P, Coldham N, Kuhnert N, Sauer MJ, Ioannides C. Modulation of hepatic cytochromes P450 and phase II enzymes by dietary doses of sulforaphane in rats: Implications for its chemopreventive activity. Int J Cancer 2005; 117: 356-62.

66 Langouet S, Furge LL, Kerriguy N, Nakamura K, Guillouzo A, Guengerich FP. Inhibition of human cytochrome P450 enzymes by 1,2-dithiole-3-thione, oltipraz and its derivatives, and sulforaphane. Chem Res Toxicol 2000; 13: 245-52.

67 Paolini M, Perocco P, Canistro D, Valgimigli L, Pedulli GF, Iori $\mathrm{R}$, et al. Induction of cytochrome $\mathrm{P} 450$, generation of oxidative stress and in vitro cell-transforming and DNA-damaging activities 
by glucoraphanin, the bioprecursor of the chemopreventive agent sulforaphane found in broccoli. Carcinogenesis 2004; 25 : 6167.

68 Tang L, Zhang Y. Dietary isothiocyanates inhibit the growth of human bladder carcinoma cells. J Nutr 2004; 134: 2004-10.

69 Shan Y, Sun C, Zhao X, Wu K, Cassidy A, Bao Y. Effect of sulforaphane on cell growth, $G(0) / G(1)$ phase cell progression and apoptosis in human bladder cancer T24 cells. Int J Oncol 2006; 29: 883-8.

70 Fimognari C, Nusse M, Cesari R, Iori R, Cantelli-Forti G, Hrelia P. Growth inhibition, cell-cycle arrest and apoptosis in human T-cell leukemia by the isothiocyanate sulforaphane. Carcinogenesis 2002; 23: 581-6.

71 Fimognari C, Nusse M, Berti F, Iori R, Cantelli-Forti G, Hrelia P. Sulforaphane modulates cell cycle and apoptosis in transformed and non-transformed human T lymphocytes. Ann N Y Acad Sci 2003; 1010: 393-8.

72 Karmakar S, Weinberg MS, Banik NL, Patel SJ, Ray SK. Activation of multiple molecular mechanisms for apoptosis in human malignant glioblastoma T98G and U87MG cells treated with sulforaphane. Neuroscience 2006; 141: 1265-80.

73 Pledgie-Tracy A, Sobolewski MD, Davidson NE. Sulforaphane induces cell type-specific apoptosis in human breast cancer cell lines. Mol Cancer Ther 2007; 6: 1013-21.

74 Gamet-Payrastre L, Li P, Lumeau S, Cassar G, Dupont MA, Chevolleau $\mathrm{S}$, et al. Sulforaphane, a naturally occurring isothiocyanate, induces cell cycle arrest and apoptosis in HT29 human colon cancer cells. Cancer Res 2000; 60: 1426-33.

75 Jakubikova J, Sedlak J, Mithen R, Bao Y. Role of PI3K/Akt and MEK/ERK signaling pathways in sulforaphane- and erucin-induced phase II enzymes and MRP2 transcription, G2/M arrest and cell death in Caco-2 cells. Biochem Pharmacol 2005; 69: 1543-52.

76 Chaudhuri D, Orsulic S, Ashok BT. Antiproliferative activity of sulforaphane in Akt-overexpressing ovarian cancer cells. Mol Cancer Ther 2007; 6: 334-45.

77 Pham NA, Jacobberger JW, Schimmer AD, Cao P, Gronda M, Hedley DW. The dietary isothiocyanate sulforaphane targets pathways of apoptosis, cell cycle arrest, and oxidative stress in human pancreatic cancer cells and inhibits tumor growth in severe combined immunodeficient mice. Mol Cancer Ther 2004; 3: 1239-48.

78 Chiao JW, Chung FL, Kancherla R, Ahmed T, Mittelman A, Conaway CC. Sulforaphane and its metabolite mediate growth arrest and apoptosis in human prostate cancer cells. Int J Oncol 2002; 20: 631-6.

79 Singh AV, Xiao D, Lew KL, Dhir R, Singh SV. Sulforaphane induces caspase-mediated apoptosis in cultured PC-3 human prostate cancer cells and retards growth of PC-3 xenografts in vivo. Carcinogenesis 2004; 25: 83-90.

80 Misiewicz I, Skupinska K, Kasprzycka-Guttman T. Sulforaphane and 2-oxohexyl isothiocyanate induce cell growth arrest and apoptosis in L-1210 leukemia and ME-18 melanoma cells. Oncol Rep 2003; 10: 2045-50.

81 Tang L, Zhang Y. Mitochondria are the primary target in isothiocyanate-induced apoptosis in human bladder cancer cells. Mol Cancer Ther 2005; 4: 1250-9.

82 Matsui TA, Sowa Y, Yoshid T, Murata H, Horinaka M, Wakada
M, et al. Sulforaphane enhances TRAIL-induced apoptosis through the induction of DR5 expression in human osteosarcoma cells. Carcinogenesis 2006; 27: 1768-77.

83 Kim H, Kim EH, Eom YW, Kim WH, Kwon TK, Lee SJ, et al. Sulforaphane sensitizes tumor necrosis factor-related apoptosisinducing ligand (TRAIL)-resistant hepatoma cells to TRAILinduced apoptosis through reactive oxygen species-mediated up-regulation of DR5. Cancer Res 2006; 66: 1740-50.

84 Singh SV, Srivastava SK, Choi S, Lew KL, Antosiewicz J, Xiao D, et al. Sulforaphane-induced cell death in human prostate cancer cells is initiated by reactive oxygen species. J Biol Chem 2005; 280: 19911-24.

85 Herman-Antosiewicz A, Johnson DE, Singh SV. Sulforaphane causes autophagy to inhibit release of cytochrome $\mathrm{C}$ and apoptosis in human prostate cancer cells. Cancer Res 2006; 66: $5828-35$.

86 Wang L, Liu D, Ahmed T, Chung FL, Conaway C, Chiao JW. Targeting cell cycle machinery as a molecular mechanism of sulforaphane in prostate cancer prevention. Int J Oncol 2004; 24: 187-92.

87 Parnaud G, Li P, Cassar G, Rouimi P, Tulliez J, Combaret L, et al. Mechanism of sulforaphane-induced cell cycle arrest and apoptosis in human colon cancer cells. Nutr Cancer 2004; 48: 198-206.

88 Jackson SJ, Singletary, K. W. Sulforaphane inhibits human MCF-7 mammary cancer cell mitotic progression and tubulin polymerization. J Nutr 2004; 134: 2229-36.

$89 \mathrm{Xu} \mathrm{C}$, Shen G, Yuan X, Kim JH, Gopalkrishnan A, Keum YS, et al. ERK and JNK signaling pathways are involved in the regulation of activator protein 1 and cell death elicited by three isothiocyanates in human prostate cancer PC-3 cells. Carcinogenesis 2006; 27: 437-45.

90 Cho SD, Li G, Hu H, Jiang C, Kang KS, Lee YS, et al. Involvement of c-Jun N-terminal kinase in G2/M arrest and caspasemediated apoptosis induced by sulforaphane in DU145 prostate cancer cells. Nutr Cancer 2005; 52: 213-24.

91 Choi S, Singh SV. Bax and Bak are required for apoptosis induction by sulforaphane, a cruciferous vegetable-derived cancer chemopreventive agent. Cancer Res 2005; 65: 2035-43.

92 Myzak MC, Karplus PA, Chung FL, Dashwood RH. A novel mechanism of chemoprotection by sulforaphane: inhibition of histone deacetylase. Cancer Res 2004; 64: 5767-74.

93 Singh SV, Herman-Antosiewicz A, Singh AV, Lew KL, Srivastava $\mathrm{SK}$, Kamath R, et al. Sulforaphane-induced G2/M phase cell cycle arrest involves checkpoint kinase 2-mediated phosphorylation of cell division cycle 25C. J Biol Chem 2004; 279: 2581322.

94 Fimognari C, Sangiorgi L, Capponcelli S, Nusse M, Fontanesi S, Berti F, et al. A mutated p53 status did not prevent the induction of apoptosis by sulforaphane, a promising anti-cancer drug. Invest New Drugs 2005; 23: 195-203.

95 Shen G, Xu C, Chen C, Hebbar V, Kong A N. p53-independent G1 cell cycle arrest of human colon carcinoma cells HT-29 by sulforaphane is associated with induction of p21CIP1 and inhibition of expression of cyclin D1. Cancer Chemother Pharmacol 2006; 57: 317-27.

96 Fimognari C, Nusse M, Lenzi M, Sciuscio D, Cantelli-Forti G, Hrelia P. Sulforaphane increases the efficacy of doxorubicin in 
mouse fibroblasts characterized by p53 mutations. Mutat Res 2006; 601: 92-101

97 Fimognari C, Lenzi M, Sciuscio D, Cantelli-Forti G, Hrelia P. Combination of doxorubicin and sulforaphane for reversing doxorubicin-resistant phenotype in mouse fibroblasts with p53Ser220 mutation. Ann N Y Acad Sci 2007; 1095: 62-9.

98 Bertl E, Bartsch H, Gerhauser C. Inhibition of angiogenesis and endothelial cell functions are novel sulforaphane-mediated mechanisms in chemoprevention. Mol Cancer Ther 2006; 5: 575-85.

99 Asakage M, Tsuno NH, Kitayama J, Tsuchiya T, Yoneyama S, Yamada J, et al. Sulforaphane induces inhibition of human umbilical vein endothelial cells proliferation by apoptosis. Angiogenesis 2006; 9: 83-91.

100 Rose P, Huang Q, Ong CN, Whiteman M. Broccoli and watercress suppress matrix metalloproteinase-9 activity and invasiveness of human MDA-MB-231 breast cancer cells. Toxicol Appl Pharmacol 2005; 209: 105-13.

101 Westermarck J, Kahari VM. Regulation of matrix metalloproteinase expression in tumor invasion. FASEB J 1999; 13: 78192.

102 Jackson SJ, Singletary KW, Venema RC. Sulforaphane suppresses angiogenesis and disrupts endothelial mitotic progression and microtubule polymerization. Vascul Pharmacol 2007; 46: 7784.

103 Thejass P, Kuttan G. Antimetastatic activity of Sulforaphane. Life Sci 2006; 78: 3043-50.

104 Thejass P, Kuttan G. Augmentation of natural killer cell and antibody-dependent cellular cytotoxicity in BALB/c mice by sulforaphane, a naturally occurring isothiocyanate from broccoli through enhanced production of cytokines IL-2 and IFNgamma. Immunopharmacol Immunotoxicol 2006; 28: 44357.

105 Heiss E, Herhaus C, Klimo K, Bartsch H, Gerhauser C. Nuclear factor kappa $\mathrm{B}$ is a molecular target for sulforaphane-mediated anti-inflammatory mechanisms. J Biol Chem 2001; 276: 3200815.

106 Ritz SA, Wan J, Diaz-Sanchez D. Sulforaphane-stimulated phase II enzyme induction inhibits cytokine production by airway epithelial cells stimulated with diesel extract. Am J Physiol Lung Cell Mol Physiol 2007; 292: L33-9.

107 Xu C, Shen G, Chen C, Gelinas C, Kong AN. Suppression of NFkappaB and NF-kappaB-regulated gene expression by sulforaphane and PEITC through IkappaBalpha, IKK pathway in human prostate cancer PC-3 cells. Oncogene 2005; 24: 4486-95.

108 Niture SK, Velu CS, Smith QR, Bhat G J, Srivenugopal KS. Increased expression of the MGMT repair protein mediated by cysteine prodrugs and chemopreventative natural products in human lymphocytes and tumor cell lines. Carcinogenesis 2007; 28: $378-89$.

109 Lee SK, Song L, Mata-Greenwood E, Kelloff GJ, Steele VE, Pezzuto JM. Modulation of in vitro biomarkers of the carcinogenic process by chemopreventive agents. Anticancer Res 1999; 19: 35-44.

110 Payen L, Courtois A, Loewert M, Guillouzo A, Fardel O. Reactive oxygen species-related induction of multidrug resistanceassociated protein 2 expression in primary hepatocytes exposed to sulforaphane. Biochem Biophys Res Commun 2001; 282:
257-63.

111 Nabekura T, Kamiyama S, Kitagawa S. Effects of dietary chemopreventive phytochemicals on P-glycoprotein function. Biochem Biophys Res Commun 2005; 327: 866-70.

112 Haristoy X, Angioi-Duprez K, Duprez A, Lozniewski A. Efficacy of sulforaphane in eradicating Helicobacter pylori in human gastric xenografts implanted in nude mice. Antimicrob Agents Chemother 2003; 47: 3982-4.

113 Chung FL, Conaway CC, Rao CV, Reddy BS. Chemoprevention of colonic aberrant crypt foci in Fischer rats by sulforaphane and phenethyl isothiocyanate. Carcinogenesis 2000; 21:228791.

114 Conaway CC, Wang CX, Pittman B, Yang YM, Schwartz JE, Tian D, et al. Phenethyl isothiocyanate and sulforaphane and their $\mathrm{N}$-acetylcysteine conjugates inhibit malignant progression of lung adenomas induced by tobacco carcinogens in $\mathrm{A} / \mathrm{J}$ mice. Cancer Res 2005; 65: 8548-57.

115 Kuroiwa Y, Nishikawa A, Kitamura Y, Kanki K, Ishii Y, Umemura $\mathrm{T}$, et al. Protective effects of benzyl isothiocyanate and sulforaphane but not resveratrol against initiation of pancreatic carcinogenesis in hamsters. Cancer Lett 2006; 241: 275-80.

116 Gills JJ, Jeffery EH, Matusheski NV, Moon RC, Lantvit DD, Pezzuto JM. Sulforaphane prevents mouse skin tumorigenesis during the stage of promotion. Cancer Lett 2006; 236: 72-9.

117 Dinkova-Kostova AT, Jenkins SN, Fahey JW, Ye L, Wehage SL, Liby KT, et al. Protection against UV-light-induced skin carcinogenesis in SKH-1 high-risk mice by sulforaphane-containing broccoli sprout extracts. Cancer Lett 2006; 240: 243-52.

$118 \mathrm{Hu}$ R, Khor TO, Shen G, Jeong WS, Hebbar V, Chen C, et al. Cancer chemoprevention of intestinal polyposis in ApcMin/+ mice by sulforaphane, a natural product derived from cruciferous vegetable. Carcinogenesis 2006; 27: 2038-46.

119 Su LK, Kinzler KW, Vogelstein B, Preisinger AC, Moser AR, Luongo $\mathrm{C}$, et al. Multiple intestinal neoplasia caused by a mutation in the murine homolog of the APC gene. Science 1992; 256: 668-70.

120 Khor TO, Hu R, Shen G, Jeong WS, Hebbar V, Chen C, et al. Pharmacogenomics of cancer chemopreventive isothiocyanate compound sulforaphane in the intestinal polyps of ApcMin/+ mice. Biopharm Drug Dispos 2006; 27: 407-20.

121 Shapiro TA, Fahey JW, Dinkova-Kostova AT, Holtzclaw WD, Stephenson KK, Wade KL, et al. Safety, tolerance, and metabolism of broccoli sprout glucosinolates and isothiocyanates: a clinical phase I study. Nutr Cancer 2006; 55: 53-62.

122 Kassahun K, Davis M, Hu P, Martin B, Baillie T. Biotransformation of the naturally occurring isothiocyanate sulforaphane in the rat: identification of phase I metabolites and glutathione conjugates. Chem Res Toxicol 1997; 10: 1228-33.

123 Ye L, Dinkova-Kostova AT, Wade KL, Zhang Y, Shapiro TA, Talalay P. Quantitative determination of dithiocarbamates in human plasma, serum, erythrocytes and urine: pharmacokinetics of broccoli sprout isothiocyanates in humans. Clin Chim Acta 2002; 316: 43-53.

124 Petri N, Tannergren C, Holst B, Mellon FA, Bao Y, Plumb GW, et al. Absorption/metabolism of sulforaphane and quercetin, and regulation of phase II enzymes, in human jejunum in vivo. Drug Metab Dispos 2003; 31: 805-13.

125 Gasper AV, Al-Janobi A, Smith JA, Bacon JR, Fortun P, Atherton 
C, et al. Glutathione S-transferase M1 polymorphism and metabolism of sulforaphane from standard and high-glucosinolate broccoli. Am J Clin Nutr 2005; 82: 1283-91.

126 Al Janobi AA, Mithen RF, Gasper AV, Shaw PN, Middleton RJ, Ortori CA, et al. Quantitative measurement of sulforaphane, iberin and their mercapturic acid pathway metabolites in human plasma and urine using liquid chromatography-tandem electrospray ionisation mass spectrometry. J Chromatogr B Analyt Technol Biomed Life Sci 2006; 844: 223-34.

127 Conaway CC, Krzeminski J, Amin S, Chung FL. Decomposition rates of isothiocyanate conjugates determine their activity as inhibitors of cytochrome p450 enzymes. Chem Res Toxicol 2001; 14: 1170-6.

128 Tang L, Li G, Song L, Zhang Y. The principal urinary metabolites of dietary isothiocyanates, $\mathrm{N}$-acetylcysteine conjugates, elicit the same anti-proliferative response as their parent compounds in human bladder cancer cells. Anticancer Drugs 2006; 17: $297-305$.

129 Hwang ES, Jeffery EH. Induction of quinone reductase by sulforaphane and sulforaphane $\mathrm{N}$-acetylcysteine conjugate in murine hepatoma cells. J Med Food 2005; 8: 198-203.

130 Zhang Y, Talalay P. Mechanism of differential potencies of isothiocyanates as inducers of anticarcinogenic Phase 2 enzymes. Cancer Res 1998; 58: 4632-9.

131 Zhang Y. Role of glutathione in the accumulation of anticarcinogenic isothiocyanates and their glutathione conjugates by murine hepatoma cells. Carcinogenesis 2000; 21: 1175-82.

132 Zhang Y. Molecular mechanism of rapid cellular accumulation of anticarcinogenic isothiocyanates. Carcinogenesis 2001;22: 425-31.

133 Zhang Y, Callaway EC. High cellular accumulation of sulphoraphane, a dietary anticarcinogen, is followed by rapid transportermediated export as a glutathione conjugate. Biochem J 2002; 364: 301-7.

134 Callaway EC, Zhang Y, Chew W, Chow HH. Cellular accumulation of dietary anticarcinogenic isothiocyanates is followed by transporter-mediated export as dithiocarbamates. Cancer Lett 2004; 204: 23-31. 